\title{
Prevalence of Select Intestinal Parasites in Alabama Backyard Poultry Flocks
}

\author{
Miranda Carrisosa ${ }^{1}$, Shanhao Jin ${ }^{2}$, Brigid A. McCrea ${ }^{3}$, Kenneth S. Macklin ${ }^{1}$, Teresa Dormitorio ${ }^{1}$ and \\ Rüdiger Hauck 1,4,*iD \\ 1 Department of Poultry Science, College of Agriculture Auburn University, Auburn, AL 36849, USA; \\ mcc0033@auburn.edu (M.C.); macklks@auburn.edu (K.S.M.); dormitv@auburn.edu (T.D.) \\ 2 College of Veterinary Medicine, Yangzhou University, Yangzhou 225009, Jiangsu, China; \\ jinshanhao00@163.com \\ 3 Alabama Cooperative Extension System, Auburn, AL 36849, USA; mccreba@auburn.edu \\ 4 Department of Pathobiology, College of Veterinary Medicine, Auburn University, Auburn, AL 36849, USA \\ * Correspondence: ruediger.hauck@auburn.edu
}

check for updates

Citation: Carrisosa, M.; Jin, S.; McCrea, B.A.; Macklin, K.S.; Dormitorio, T.; Hauck, R. Prevalence of Select Intestinal Parasites in Alabama Backyard Poultry Flocks. Animals 2021, 11, 939. https:// doi.org/10.3390/ani11040939

Academic Editor: Jan Jankowski

Received: 4 March 2021

Accepted: 24 March 2021

Published: 26 March 2021

Publisher's Note: MDPI stays neutral with regard to jurisdictional claims in published maps and institutional affiliations.

Copyright: (c) 2021 by the authors. Licensee MDPI, Basel, Switzerland. This article is an open access article distributed under the terms and conditions of the Creative Commons Attribution (CC BY) license (https:// creativecommons.org/licenses/by/ $4.0 /)$.
Simple Summary: As biosecurity is generally low in backyard chicken flocks, infections with various pathogens are common. This puts other poultry nearby, including commercial flocks, at risk. Some chicken pathogens can also infect humans and cause disease. In this study, backyard poultry flocks were tested for parasites. Eighty-four fecal samples, 82 from chickens and two from turkeys, from 64 backyard flocks throughout the state of Alabama were collected in the summers of 2017 and 2018. The most frequently observed parasites were coccidia, unicellular parasites capable of causing diarrhea. Eggs of various roundworms were observed in $20.3-26.6 \%$ of the flocks. These parasites were usually present in low numbers only. Other detected parasites were the flagellates Histomonas meleagridis and Tetratrichomonas gallinarum in $4.7 \%$ and $18.8 \%$ of flocks. Both can cause severe disease in poultry. Detected parasites that can cause disease in humans were Cryptosporidium spp. in 18.8\% of the flocks and Blastocystis spp. in $87.5 \%$ of the flocks. The results will help to provide information that can be used to design outreach programs to improve the health and wellbeing of birds in backyard flocks.

Abstract: Keeping chickens as backyard pets has become increasingly popular in the United States in recent years. However, biosecurity is generally low in backyard flocks. As a consequence, they can serve as reservoirs for various pathogens that pose a risk for commercial poultry or human health. Eighty-four fecal samples, 82 from chickens and two from turkeys, from 64 backyard flocks throughout the state of Alabama were collected in the summers of 2017 and 2018. Coccidia oocysts were seen in $64.1 \%$ of flocks with oocyst counts in most samples below 10,000 oocysts per gram. Eggs of Ascaridia spp. or Heterakis gallinarum were observed in $20.3 \%$ of the flocks, and eggs of Capillaria spp. in $26.6 \%$ of the flocks. Egg counts were low, rarely exceeding 1000 eggs per gram. DNA extracted directly from fecal samples was investigated by PCR for other relevant parasites. The results showed that $4.7 \%$ of flocks were positive for Histomonas meleagridis, $18.8 \%$ of flocks for Tetratrichomonas gallinarum, $18.8 \%$ of flocks for Cryptosporidium spp. and $87.5 \%$ of flocks for Blastocystis spp. The results will help to provide information that can be used to design outreach programs to improve health and wellbeing of birds in backyard flocks.

Keywords: epidemiology; Eimeria; coccidia; nematodes; zoonosis

\section{Introduction}

Over the past two decades, there has been an apparent increase in backyard flocks in the United States [1-6]. "Backyard flock" is a term that generally refers to a privately owned flock of poultry, more often chickens than turkeys, that are kept at a residence. The most common reasons for backyard flock ownership in the United States are to keep the 
chickens as pets, a learning tool for children or as a source of eggs [3]. In other parts of the world, small non-commercial chicken flocks are referred to as village chickens and contribute to the subsistence of their owners [7].

Regardless of the location, many of these small flock owners tend to lack knowledge of proper biosecurity measures, e.g., wearing designated clothes/shoes, not allowing guests to interact with the chickens. They are not aware of the risks associated with exposing their flock to wild birds and rodents $[3,8,9]$. Zoonotic avian diseases such as salmonellosis are a risk for small flock owners, either by direct contact with backyard poultry flocks or by consumption of contaminated meat or eggs $[10,11]$. Low biosecurity in backyard flocks may also be an issue for commercial poultry flocks as backyard flocks can become a reservoir for pathogens [12]. This is especially relevant in a state like Alabama, which ranks second in broiler production in the United States [13].

Eimeria spp. are considered ubiquitous in chicken flocks [14]. However, their prevalence in village chickens can be between less than $5 \%[15,16]$ and up to more than $60 \%[17]$. Roundworms, mostly Ascaridia galli and Heterakis gallinarum, have been detected in 15-25\% of chickens by coproscopy [15,18] and up to $80 \%$ by visual inspection of intestines [19]. In $25 \%$ of dead village chickens, helminths were regarded as causative factor for the loss [20]. Currently, limited information is available about parasites found in backyard flocks in the United States. In birds submitted from backyard flocks to eight veterinary diagnostic laboratories across the United States, internal parasites were regarded as the primary cause of mortality in $2.6 \%$ of the birds. However, parasitic infections were the most common secondary finding, being observed in $25.5 \%$ of the birds [1].

The aim of the present study was to determine the population of relevant parasitic organisms found in backyard poultry flocks without ongoing disease.

\section{Materials and Methods}

\subsection{Sample Collection}

Eighty-four fecal samples from 64 different, non-commercial backyard flocks with less than 50 chickens throughout the state of Alabama were included in the study. The flocks were selected opportunistically, and pooled fecal samples of 10 to $50 \mathrm{~g}$ were collected in Ziploc bags and submitted by the owners. Forty-seven samples from 41 flocks were submitted in the summer of 2017 and 37 samples from 23 flocks in the summer of 2018. Two of the fecal samples were from turkeys kept on the same premises with sampled chickens. Each sample was stored at $4{ }^{\circ} \mathrm{C}$ upon arrival for microscopy and at $-20{ }^{\circ} \mathrm{C}$ for DNA extraction. Four owners submitted samples of their flocks in both 2017 and 2018; however, in the present study they are considered different flocks.

\subsection{Oocysts and Nematode Egg Detection}

Each fecal sample was mixed thoroughly, and $1 \mathrm{~g}$ was suspended in $29 \mathrm{~mL}$ saturated $\mathrm{NaCl}$ solution. Debris was filtered out through a sieve. A McMaster chamber was filled with the fecal mixture and placed on a microscope where Eimeria spp. oocysts and nematode eggs were counted. The total number of oocysts and eggs in the chambers were multiplied by 100 to obtain the oocysts per gram (opg) and eggs per gram (epg) [21,22]. Eimeria oocysts were between 10 and $30 \mu \mathrm{m}$ long and between 10 and $20 \mu \mathrm{m}$ wide with a thick, double layered, smooth oocyst wall. Some oocysts were sporulated while most were not. Ascaridia spp. and H. gallinarum eggs were between 75 and $80 \mu \mathrm{m}$ long and between 45 and $50 \mu \mathrm{m}$ wide with a thick, smooth shell. Ascaridia spp. and H. gallinarum eggs were not differentiated due to similar egg morphology [23,24]. Capillaria eggs were about $70 \mu \mathrm{m}$ long and $30 \mu \mathrm{m}$ wide, with a thick smooth shell and two polar plugs.

\subsection{Oocyst Purification and $q P C R$ to Detect Eimeria}

Oocysts were purified and concentrated from $4 \mathrm{~g}$ feces of 47 samples with Eimeria oocysts as described by Hafeez et al. [25]. Three positive samples were not further processed due to lack of material. DNA was extracted from the purified oocysts using the QIAGEN 
QiaAmp DNA mini kit (QIAGEN, Valencia, CA, USA) according to the manufacturer's protocol, and Eimeria DNA was quantified by qPCR with 45 cycles detecting Eimeria $5 \mathrm{~S}$ rDNA as described $[26,27]$. DNA load was expressed as the number of the cycles of the qPCR minus the quantification cycle (Cq). Its correlation with the parasite load in opg was assessed by calculating Spearman's rho using R 3.6.0 [28].

\subsection{Stool DNA Extraction and PCR for Other Parasites}

DNA was extracted from one fecal sample per flock using the QIAGEN QIAamp Stool Mini Kit according to the manufacturer's instructions (QIAGEN, Valencia, CA, USA). Histomonas meleagridis, Tetratrichomonas gallinarum, Blastocystis spp., and Cryptosporidium spp. and were detected by PCR using established protocols. Primers and references are listed in Table 1. Positive and negative controls were included in all PCR runs, and a negative control was included in all DNA extractions.

Table 1. Nucleotide sequences and references of the primers used to detect the parasites in fecal samples of backyard chicken flocks.

\begin{tabular}{|c|c|c|c|c|}
\hline \multirow{2}{*}{ Species } & \multicolumn{2}{|c|}{ Sequences } & \multirow{2}{*}{$\begin{array}{l}\text { Amplicon Size } \\
\text { in Base Pairs }\end{array}$} & \multirow{2}{*}{ Reference } \\
\hline & Forward $\left(5^{\prime}-3^{\prime}\right)$ & Reverse $\left(5^{\prime}-3^{\prime}\right)$ & & \\
\hline \multirow[b]{2}{*}{ Eimeria spp. } & TCA TCA CCC AAA GGG ATT & $\begin{array}{c}\text { TTC ATA CTG CGT CTA ATG } \\
\text { CAC }\end{array}$ & \multirow[b]{2}{*}{$\sim 110$} & \multirow{2}{*}[26]{} \\
\hline & \multicolumn{2}{|c|}{$\begin{array}{c}\text { Probe: [6-FAM] CGC CGC TTA ACT TCG GAG TTC AGA TGG GAT } \\
\text { [BHQ-1] }{ }^{1}\end{array}$} & & \\
\hline Blastocystis spp. & $\begin{array}{l}\text { TAA CCG TAG TAA TTC TAG } \\
\text { GGC }\end{array}$ & $\begin{array}{c}\text { AAC GTT AAT ATA CGC TAT } \\
\text { TGG }\end{array}$ & 459 & [29] \\
\hline $\begin{array}{l}\text { Cryptosporidium spp. } \\
\text { (outer) }\end{array}$ & TTC TAG AGC TAA TAC ATG CG & $\begin{array}{c}\text { CCC TAA TCC TTC GAA ACA } \\
\text { GGA }\end{array}$ & 1325 & {$[30]$} \\
\hline $\begin{array}{l}\text { Cryptosporidium spp. } \\
\text { (nested) }\end{array}$ & $\begin{array}{c}\text { GGA AGG GTT GTA TTT ATT } \\
\text { AGA TAA AG }\end{array}$ & $\begin{array}{c}\text { AAG GAG TAA GGA ACA ACC } \\
\text { TCC A }\end{array}$ & 830 & {$[30]$} \\
\hline Histomonas meleagridis & CCG TGA TGT CCT TTA GAT GC & $\begin{array}{c}\text { GAT CTT TTC AAA TTA GCT } \\
\text { TTA AAT TAT TC }\end{array}$ & 603 & {$[31]$} \\
\hline $\begin{array}{l}\text { Tetratrichomonas } \\
\text { gallinarum }\end{array}$ & $\begin{array}{c}\text { GCA ATT GTT TCT CCA GAA } \\
\text { GTG }\end{array}$ & GAT GGC TCT CTT TGA GCT TG & 526 & [29] \\
\hline
\end{tabular}

${ }^{1}$ 6-Carboxyfluorescein; Black Hole Quencher.

\section{Results}

\subsection{Eimeria and Nematode Prevalence}

Eimeria were detected in 41 flocks (64.1\%) and 50 samples (59.5\%). Median parasite load was 800 opg; however, several samples had greater than 10,000 opg. In the two samples from turkeys, no coccidia were observed. Ascaridia spp. or H. gallinarum eggs were detected in 13 flocks (20.3\%) and 16 samples (19.0\%), while Capillaria spp. were present in 17 flocks $(26.6 \%)$ and 22 samples $(26.2 \%)$. Median epg for all nematodes was less than 500 (Table 2, Figure 1). In one of the two samples from turkeys, 200 epg Ascaridia spp. or H. gallinarum eggs were observed. Of the four flocks that submitted samples in both 2017 and 2018, one flock had a change in status for coccidia from negative to positive and two had changes in Ascaridia/Heterakis egg status from negative to positive. There were no changes in status for Capillaria spp. eggs from year 2017 and 2018. 
Table 2. Prevalence of Eimeria spp. oocysts and nematodes eggs in fecal samples of backyard chicken flocks and median oocysts (OPG) and eggs per gram (EPG).

\begin{tabular}{cccc}
\hline Species & $\begin{array}{c}\text { Positive Samples } \\
(\boldsymbol{n}=\mathbf{8 4 )}\end{array}$ & $\begin{array}{c}\text { Positive Flocks } \\
(\boldsymbol{n}=\mathbf{6 4 )}\end{array}$ & $\begin{array}{c}\text { Median } \\
\text { opg/epg }\end{array}$ \\
\hline Eimeria spp. & $50(59.5 \%)$ & $41(64.1 \%)$ & 800 \\
Ascaridia galli/Heterakis gallinarum & $16(19 \%)$ & $13(20.3 \%)$ & 350 \\
Capillaria spp. & $22(26.2 \%)$ & $17(26.6 \%)$ & 200 \\
Histomonas meleagridis & n.a. ${ }^{1}$ & $3(4.7 \%)$ & n.a. ${ }^{2}$ \\
Tetratrichimonas gallinarum & n.a. & $12(18.8 \%)$ & n.a. \\
Cryptosporidium spp. & n.a. & $12(18.8 \%)$ & n.a. \\
Blastocystis spp. & n.a. & $56(87.5 \%)$ & n.a. \\
\hline
\end{tabular}

${ }^{1}$ not applicable because only one sample per flock was investigated ${ }^{2}$ not applicable because no quantitative test.

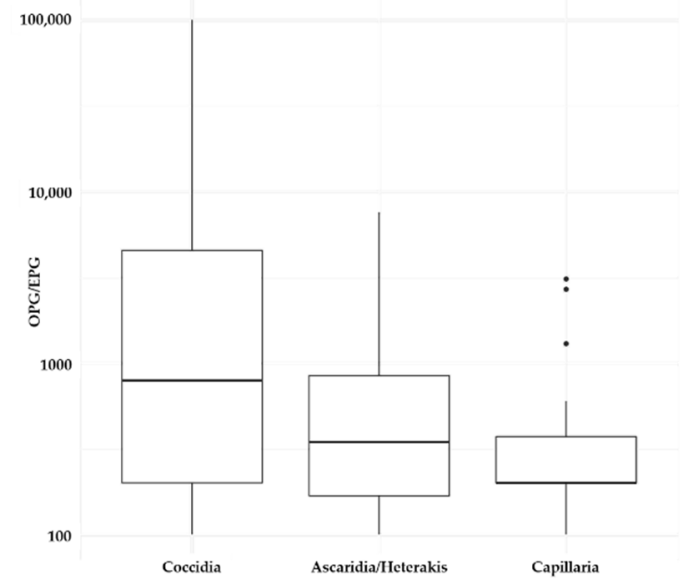

Figure 1. Coccidia oocysts per gram feces (OPG) and Ascaricdia galli/Heterakis gallinarum eggs per gram feces (EPG) detected in fecal samples of backyard chicken flocks shown on log scale.

\subsection{Quantification of Eimeria Oocysts by qPCR}

The 5S rDNA qPCR failed to detect Eimeria DNA in four samples with 100 opg (two samples), 4000 opg, and 30,800 opg. A spearman's rho of 0.31 showed only a weak correlation between the parasite load seen in the feces and the DNA load detected by qPCR (Figure 2).

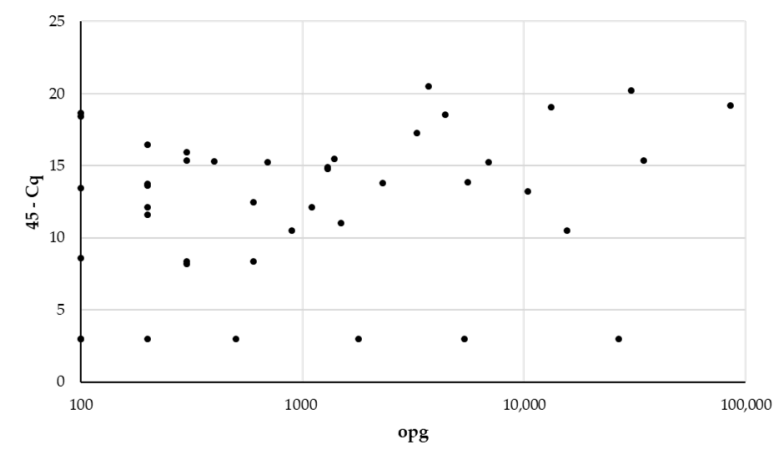

Figure 2. Scatterplot correlating the number of coccidia oocysts per gram feces (opg) and the detected DNA load expressed as the number of the cycles of the qPCR minus the quantification cycle Cq.

\subsection{Prevalence of Other Parasites}

Of the 64 DNA samples, one from each flock, tested by PCR, 4.7\% were positive for H. meleagridis, $18.8 \%$ for T. gallinarum, $18.8 \%$ for Cryptosporidium spp., and $87.5 \%$ for Blastocystis spp. (Table 2). Of the four flocks whose owners submitted samples in both 2017 and 2018, only one flock had a change in status for both T. gallinarum and Blastocystis spp. 
with the flock being positive in 2017 but negative in 2018. There were no changes in any of the other species of parasites in the flocks that submitted samples in both years.

\section{Discussion}

Backyard flocks may be a concern to public health and the commercial industry as they could potentially be a reservoir for pathogens. This is due to the fact that many of these flocks have poor biosecurity and have frequent access to the outdoors, which allows them to come in contact with wild birds and other animals, such as rodents, that can transmit disease [6,32].

In the present study, Eimeria spp. oocysts were detected in $59.5 \%$ of the samples and $64.1 \%$ of the flocks and counts in most samples were low. This reflected the equilibrium between infection and immunity present in older chickens, as well as the lower stocking density in extensively kept, often free ranging backyard flocks [3], which decreases the infection pressure. Compared to the prevalence of Eimeria spp. reported in village chickens, which ranges from less than $5 \%[15,16]$ up to more than $60 \%$ [17], this was comparatively high. One of the most important factors influencing the prevalence of Eimeria spp. in small flocks is the season $[16,33,34]$. In India, prevalence varied between $61 \%$ during monsoon season, i.e., warm and humid conditions, and $22 \%$ during the preceding cooler months [35]. The prevalence in the samples of this study taken during summer in Alabama was similar to the former number.

Four samples in which coccidia oocysts were observed, tested negative by qPCR. One likely reason for the discrepancy is a lack of sensitivity of the qPCR: two of the samples in question contained only $100 \mathrm{opg}$. On the other hand, two samples with considerably higher oocyst counts tested negative as well. The most likely reason is that the observed oocysts were not Eimeria infecting chickens but other coccidia, including Eimeria spp. infecting other hosts; the primers of this qPCR were designed based on sequences of Eimeria infecting chickens [26] and might not amplify other Eimeria spp. or coccidia. In fact, Eimeria from other hosts such as squirrels and mice were detected in some of the samples when amplified by pan-Eimeria PCR primers [27], potentially the result of coprophagy by chickens or contamination of the samples with feces from other hosts.

There was only a weak correlation between the parasite load seen in the feces and the DNA load detected by qPCR. The reasons probably include the presence of Eimeria from other hosts in addition to varying losses of oocysts during the purification of the oocysts and age of the samples. Testing samples from commercial poultry by the same methods showed a better correlation and no sample in which Eimeria oocysts had been seen tested negative by qPCR (results not shown).

A prevalence of $20 \%$ for eggs of A. galli or $\mathrm{H}$. gallinarum and $26 \%$ for eggs of Capillaria spp. in the present study were similar to the prevalence of these parasites in village chickens in Africa when fecal samples were investigated [15,18]. However, the prevalence was lower than in organic layer chickens in Europe, where flock prevalence of the two parasites was between $49.3 \%$ and 100\% [24]. However, the mean of 576 epg was similar to the results presented here [24].

Since coccidia and roundworms were the most encountered parasites in similar studies, they were our primary target and consequently flotation was used for detection. However, flotation might not be the most suitable method for tapeworm eggs, and we might have missed infections with those.

In European commercial pullet and layer flocks, antibodies against $H$. meleagridis were detected in up to $37.3 \%$ of the tested birds and $89.3 \%$ of the tested flocks [36,37]. In contrast, in the present study, the prevalence as detected by PCR was extremely low. This compares to findings by Cadmus et al. [1] who diagnosed histomoniasis based on lesions only in very few chickens. No nematode eggs were detected in the samples that tested positive for $H$. meleagridis. Unfortunately, these samples were very dry, which decreased the likelihood to detect nematode eggs. 
In commercial poultry in Germany, T. gallinarum DNA was detected in $17.7 \%$ of flocks in which lesions resembling histomoniasis were observed, which is similar to the flock prevalence found here [38]. To our knowledge, there are no previous studies investigating its prevalence in commercial or backyard poultry without reported disease. In the present study, a single flock had a concurrent infection with both T. gallinarum and H. meleagridis.

Zoonotic parasites that were investigated included Cryptosproidium spp. and Blastocystis spp. There are several species of Cryptosporidium that are known zoonotic agents. Cryptosporidium spp. can cause intestinal disease in humans [39]. Cryptosporidium meleagridis, an avian pathogen, has been shown to be increasingly important as a human pathogen as it makes up 10-20\% of human cryptosporidiosis cases in Peru and Thailand [40]. Due to the low host specificity of C. meleagridis and other Cryptosporidium spp., it is important for backyard flock owners to be aware of this and improve biosecurity as they could potentially become ill.

Blastocystis spp. are very common in chickens and seem to have a low host specificity. Blastocystis infections in humans may result in clinical symptoms such as diarrhea, abdominal cramps, and nausea. However, it is unclear if Blastocystis spp. infecting chickens can cause disease in humans [41,42]. In this study, there was a high prevalence of Blastocystis spp. with $87.5 \%$ of backyard flocks being infected. This is unsurprising as another study found a Blastocystis prevalence of $95 \%$ in commercial chickens [43].

Overall, only one flock was free of the parasites investigated and 11 flocks were only infected with a single parasite. Fifty-two flocks had concurrent infection with two or more of the selected parasites. However, prevalence of the investigated parasites in backyard flocks was lower than expected as chickens with access to the outdoors generally have higher rates of parasites [44,45].

The comparatively low prevalence of parasites is likely underestimated. Shedding patterns of the parasites may have an effect on the results. Eimeria are shed in variable amounts based on days post-infection [46]. Compared to our and similar results using coproscopy, detecting worms macroscopically during necropsy resulted in significantly higher prevalence of more than $65 \%$ [19,47]. A study that looked into diurnal fluctuations of nematode egg excretion found that egg shedding was higher during the day, early morning to noon, than in the afternoon and night [48], and H. meleagridis is shed only intermittently from chronically infected chickens [49]. In addition, sample quality was not always optimal due to flock owners collecting samples and not properly storing them; and for some parasites the McMaster flotation method using $1 \mathrm{~g}$ of feces, especially of pooled samples, may be too insensitive to show all present dispersive forms of parasites.

\section{Conclusions}

We detected a variety of poultry parasites in the investigated flocks, posing a risk to commercial poultry and their owners. The results of this study will help to provide information to owners of backyard chicken flocks that can be used to design timely and appropriate extension/outreach material. Informing them of the types of internal parasites typically observed and what steps can be implemented to improve the health and wellbeing of birds will improve the overall health of backyard flocks. In addition, alerting flock owners of potential zoonotic parasites that are present in their backyard flock may lead to improvements in their biosecurity measures.

Author Contributions: Conceptualization, B.A.M. and R.H.; Formal analysis, M.C.; Funding acquisition, K.S.M. and R.H.; Investigation, M.C., S.J. and T.D.; Writing—original draft, M.C.; Writingreview and editing, B.A.M., K.S.M., T.D. and R.H. All authors have read and agreed to the published version of the manuscript.

Funding: This project was supported by the Alabama Agricultural Experiment Station and the Hatch program of the National Institute of Food and Agriculture, U.S. Department of Agriculture to R. H. (1016550) and the Animal Health and Disease Research (AHDR) program, College of Veterinary Medicine, Auburn University. 
Institutional Review Board Statement: Not applicable.

Data Availability Statement: All data is contained within the article.

Acknowledgments: We want to thank the owners of the backyard flocks for collecting and submitting the samples.

Conflicts of Interest: The authors declare no conflict of interest. The funders had no role in the design of the study; in the collection, analyses, or interpretation of data; in the writing of the manuscript, or in the decision to publish the results.

\section{References}

1. Cadmus, K.J.; Mete, A.; Harris, M.; Anderson, D.; Davison, S.; Sato, Y.; Helm, J.; Boger, L.; Odani, J.; Ficken, M.D.; et al. Causes of mortality in backyard poultry in eight states in the United States. J. Vet. Diagn. Invest. 2019, 31, 318-326. [CrossRef]

2. Crespo, R.; Senties-Cue, G. Postmortem survey of disease conditions in backyard poultry. J. Exot. Pet. Med. 2015, 24, 156-163. [CrossRef]

3. Elkhoraibi, C.; Blatchford, R.A.; Pitesky, M.E.; Mench, J.A. Backyard chickens in the United States: A survey of flock owners. Poult. Sci. 2014, 93, 2920-2931. [CrossRef]

4. Pollock, S.L.; Stephen, C.; Skuridina, N.; Kosatsky, T. Raising chickens in city backyards: The public health role. J. Community Health 2012, 37, 734-742. [CrossRef]

5. Tobin, M.R.; Goldshear, J.L.; Price, L.B.; Graham, J.P.; Leibler, J.H. A framework to reduce infectious disease risk from urban poultry in the United States. Public Health Rep. 2015, 130, 380-391. [CrossRef]

6. Whitehead, M.L.; Roberts, V. Backyard poultry: Legislation, zoonoses and disease prevention. J. Small Anim. Pract. 2014, 55, 487-496. [CrossRef]

7. Desta, T.T. Indigenous village chicken production: A tool for poverty alleviation, the empowerment of women, and rural development. Trop. Anim. Health Prod. 2020, 53, 1. [CrossRef] [PubMed]

8. Karabozhilova, I.; Wieland, B.; Alonso, S.; Salonen, L.; Häsler, D.B. Backyard chicken keeping in the Greater London Urban Area: Welfare status, biosecurity and disease control issues. Br. Poult. Sci. 2012, 53, 421-430. [CrossRef]

9. Olaniyan, O.F.; Camara, S. Rural household chicken management and challenges in the upper river region of the Gambia. Trop. Anim. Health Prod. 2018, 50, 1921-1928. [CrossRef] [PubMed]

10. Jajere, S.M.; Hassan, L.; Abdul Aziz, S.; Zakaria, Z.; Abu, J.; Nordin, F.; Faiz, N.M. Salmonella in native "village" chickens (Gallus domesticus): Prevalence and risk factors from farms in south-central peninsular Malaysia. Poult. Sci. 2019, 98, 5961-5970. [CrossRef] [PubMed]

11. Center of Disease Control. Outbreak of Salmonella Infections Linked to Backyard Poultry. 2019. Available online: https: / / www.cdc.gov/salmonella/backyardpoultry-05-19/index.html (accessed on 3 March 2021).

12. Derksen, T.; Lampron, R.; Hauck, R.; Pitesky, M.; Gallardo, R.A. Biosecurity assessment and seroprevalence of respiratory diseases in backyard poultry flocks located close and far from commercial premises. Avian Dis. 2018, 65, 1-5. [CrossRef]

13. USDA Poultry_Production and Value 2019 Summary; National Agricultural Statistics Service location: Washington, DC, USA, 2020; ISSN 1949-1573.

14. Cervantes, H.M.; McDougald, L.R.; Jenkins, M.C. Coccidiosis. In Diseases of Poultry; Swayne, D.E., Boulianne, M., Logue, C.M., McDougald, L.R., Nair, V., Suarez, D.L., Eds.; Wiley-Blackwell: Hoboken, NJ, USA, 2020; pp. 1193-1217.

15. Kelly, P.J.; Chitauro, D.; Rohde, C.; Rukwava, J.; Majok, A.; Davelaar, F.; Mason, P.R. Diseases and management of backyard chicken flocks in Chitungwiza, Zimbabwe. Avian Dis. 1994, 38, 626-629. [CrossRef] [PubMed]

16. Lawal, J.R.; Jajere, S.M.; Ibrahim, U.I.; Geidam, Y.A.; Gulani, I.A.; Musa, G.; Ibekwe, B.U. Prevalence of coccidiosis among village and exotic breed of chickens in Maiduguri, Nigeria. Vet. World 2016, 9, 653-659. [CrossRef]

17. Hadipour, M.M.; Olyaie, A.; Naderi, M.; Azad, F.; Nekouie, O. Prevalence of Eimeria species in scavenging native chickens of Shiraz, Iran. Afr. J. Microbiol. Res. 2011, 5, 3296-3299.

18. Mwale, M.; Masika, P. Point prevalence study of gastro-intestinal parasites in village chickens of Centane district, South Africa. Afr. J. Agric. Res. 2011, 6, 2033-2038. [CrossRef]

19. Ssenyonga, G.S. Prevalence of helminth parasites of domestic fowl (Gallus domesticus) in Uganda. Trop. Anim. Health Prod. 1982, 14, 201-204. [CrossRef]

20. Gondwe, T.N.; Wollny, C.B.A. Local chicken production system in Malawi: Household flock structure, dynamics, management and health. Trop. Anim. Health Prod. 2007, 39, 103-113. [CrossRef] [PubMed]

21. Conway, D.P.; McKenzie, M.E. Preparation of Oocysts. In Poultry Coccidiosis; Blackwell Publishing Professional: Ames, IA, USA, 2007; pp. 41-47, ISBN 978-0-470-34462-0.

22. Holdsworth, P.A.; Conway, D.P.; McKenzie, M.E.; Dayton, A.D.; Chapman, H.D.; Mathis, G.F.; Skinner, J.T.; Mundt, H.-C.; Williams, R.B. World Association for the Advancement of Veterinary Parasitology (WAAVP) guidelines for evaluating the efficacy of anticoccidial drugs in chickens and turkeys. Vet. Parasitol. 2004, 121, 189-212. [CrossRef] [PubMed]

23. Christenson, R.O.; Earle, H.H.; Butler, R.L.; Creel, H.H. Studies on the eggs of Ascaridia galli and Heterakis gallinae. Trans. Am. Microsc. Soc. 1942, 61, 191-205. [CrossRef] 
24. Thapa, S.; Hinrichsen, L.K.; Brenninkmeyer, C.; Gunnarsson, S.; Heerkens, J.L.T.; Verwer, C.; Niebuhr, K.; Willett, A.; Grilli, G.; Thamsborg, S.M.; et al. Prevalence and magnitude of helminth infections in organic laying hens (Gallus gallus domesticus) across Europe. Vet. Parasitol. 2015, 214, 118-124. [CrossRef] [PubMed]

25. Hafeez, M.A.; Shivaramaiah, S.; Dorsey, K.M.; Ogedengbe, M.E.; El-Sherry, S.; Whale, J.; Cobean, J.; Barta, J.R. Simultaneous identification and dna barcoding of six Eimeria species infecting turkeys using PCR primers targeting the mitochondrial cytochrome $\mathrm{C}$ oxidase subunit I (MtCOI) Locus. Parasitol. Res. 2015, 114, 1761-1768. [CrossRef]

26. Blake, D.P.; Hesketh, P.; Archer, A.; Shirley, M.W.; Smith, A.L. Eimeria Maxima: The influence of host genotype on parasite reproduction as revealed by quantitative real-time PCR. Int. J. Parasitol. 2006, 36, 97-105. [CrossRef]

27. Hauck, R.; Carrisosa, M.; McCrea, B.A.; Dormitorio, T.; Macklin, K.S. Evaluation of next-generation amplicon sequencing to identify Eimeria spp. of chickens. Avian Dis. 2019, 63, 577-583. [CrossRef] [PubMed]

28. R Core Team. R: A Language and Environment for Statistical Computing; R Foundation for Statistical Computing: Vienna, Austria, 2019; Available online: https:/ / www.r-project.org/about.html (accessed on 3 March 2021).

29. Grabensteiner, E.; Hess, M. PCR for the identification and differentiation of Histomonas meleagridis, Tetratrichomonas gallinarum and Blastocystis spp. Vet. Parasitol. 2006, 142, 223-230. [CrossRef] [PubMed]

30. Helmy, Y.A.; Krücken, J.; Abdelwhab, E.-S.M.; von Samson-Himmelstjerna, G.; Hafez, H.M. Molecular diagnosis and characterization of Cryptosporidium spp. in turkeys and chickens in Germany reveals evidence for previously undetected parasite species. PLoS ONE 2017, 12, e0177150. [CrossRef] [PubMed]

31. Hauck, R.; Hafez, H.M. Pigeons are not susceptible to intracloacal infection with Histomonas meleagridis. Pak. Vet. J. 2012, 32, 589-592.

32. Pohjola, L.; Nykäsenoja, S.; Kivistö, R.; Soveri, T.; Huovilainen, A.; Hänninen, M.L.; Fredriksson-Ahomaa, M. Zoonotic public health hazards in backyard chickens. Zoonoses Public Health 2016, 63, 420-430. [CrossRef] [PubMed]

33. Al-Gawad, A.A.; Mahdy, O.A.; El-Massry, A.A.N.; Al-Aziz, M.S.A. Studies on coccidia of Egyptian Balady breed chickens. Life Sci. J. 2012, 9, 568-576.

34. Kaboudi, K.; Umar, S.; Munir, M.T. Prevalence of coccidiosis in free-range chicken in Sidi Thabet, Tunisia. Scientifica 2016, 7075195. [CrossRef] [PubMed]

35. Sharma, S.; Iqbal, A.; Azmi, S.; Mushtaq, I.; Wani, Z.A.; Ahmad, S. Prevalence of poultry coccidiosis in Jammu region of Jammu \& Kashmir State. J. Parasit. Dis. 2015, 39, 85-89. [CrossRef]

36. Grafl, B.; Liebhart, D.; Windisch, M.; Ibesich, C.; Hess, M. Seroprevalence of Histomonas meleagridis in pullets and laying hens determined by ELISA. Vet. Rec. 2011, 168, 160-163. [CrossRef] [PubMed]

37. van der Heijden, H.M.J.F.; Landman, W.J.M. High seroprevalence of Histomonas meleagridis in Dutch layer chickens. Avian Dis. 2011, 55, 324-327. [CrossRef]

38. Hauck, R.; Balczulat, S.; Hafez, H.M. Detection of DNA of Histomonas meleagridis and Tetratrichomonas gallinarum in German poultry flocks between 2004 and 2008. Avian Dis. 2010, 54, 1021-1025. [CrossRef] [PubMed]

39. Chappell, C.L.; Okhuysen, P.C.; Langer-Curry, R.; Widmer, G.; Akiyoshi, D.E.; Tanriverdi, S.; Tzipori, S. Cryptosporidium hominis: Experimental challenge of healthy adults. Am. J. Trop. Med. Hyg. 2006, 75, 851-857. [CrossRef] [PubMed]

40. Xiao, L.; Feng, Y. Zoonotic Cryptosporidiosis. FEMS Immunol. Med. Microbiol. 2008, 52, 309-323. [CrossRef]

41. Souppart, L.; Sanciu, G.; Cian, A.; Wawrzyniak, I.; Delbac, F.; Capron, M.; Dei-Cas, E.; Boorom, K.; Delhaes, L.; Viscogliosi, E. Molecular epidemiology of human Blastocystis isolates in France. Parasitol. Res. 2009, 105, 413. [CrossRef]

42. Tan, K.S.W. Blastocystis in humans and animals: New Insights Using Modern Methodologies. Vet. Parasitol. 2004, 126, 121-144. [CrossRef]

43. Lee, M.G.; Stenzel, D.J. A survey of Blastocystis in domestic chickens. Parasitol. Res. 1999, 85, 109-117. [CrossRef]

44. Kaufmann, F.; Daş, G.; Sohnrey, B.; Gauly, M. Helminth infections in laying hens kept in organic free range systems in Germany. Livest. Sci. 2011, 141, 182-187. [CrossRef]

45. Permin, A.; Bisgaard, M.; Frandsen, F.; Pearman, M.; Kold, J.; Nansen, P. Prevalence of gastrointestinal helminths in different poultry production systems. Br. Poult. Sci. 1999, 40, 439-443. [CrossRef]

46. MyungJo, Y. The comparative analysis of infection pattern and oocyst output in Eimeria tenella, E. maxima and E. acervulina in young broiler chicken. Vet. World 2014, 7, 542-547.

47. Van, N.T.B.; Yen, N.T.P.; Nhung, N.T.; Cuong, N.V.; Kiet, B.T.; Hoang, N.V.; Hien, V.B.; Chansiripornchai, N.; Choisy, M.; Ribas, A.; et al. Characterization of viral, bacterial, and parasitic causes of disease in small-scale chicken flocks in the Mekong Delta of Vietnam. Poult. Sci. 2020, 99, 783-790. [CrossRef] [PubMed]

48. Wongrak, K.; Gauly, M.; Daş, G. Diurnal fluctuations in nematode egg excretion in naturally and in experimentally infected chickens. Vet. Parasitol. 2015, 208, 195-203. [CrossRef]

49. Hess, M.; Grabensteiner, E.; Liebhart, D. Rapid Transmission of the protozoan parasite Histomonas meleagridis in turkeys and specific pathogen free chickens following cloacal infection with a mono-eukaryotic culture. Avian Pathol. 2006, 35, 280-285. [CrossRef] [PubMed] 